International Journal of Language and Literary Studies

Volume 1, Issue 2, 2019

Homepage : http://ijlls.org/index.php/ijlls

\title{
Dramatic Transformation: The Hamlet-Type in Shakespeare's and Chekhov's Versions
}

\author{
Fuad Abdul Muttaleb \\ Professor of English, Department of English, Jerash University, Jordan. \\ fuadmuttalib@yahoo.co.uk
}

Received:
22/07/2019
Shakespeare wrote Hamlet at the very beginning of the seventeenth century, at
the height of his creative powers. It is arguably the most popular and famous
play ever written, and its hero seems to have exerted a huge fascination over
theatre audiences of every age, nation, colour and creed. Shakespeare often
borrowed plots and ideas from different sources, but they were transformed by
his poetry and his dramatic talents, and this applies largely to Hamlet. He
used an early version of Hamlet and rewrote it to suite his own idea and
Shakespeare,
Chekhov's Drama,
Russian Hamlet,
Dramatic
Transformation $\quad \begin{aligned} & \text { Elizabeth I while creating his paly. A lot has been said and written about this } \\ & \text { to discuss and consolidate the argument about the transformation of the type } \\ & \text { and the drama. In the same way Shakespeare anglicized the type of Hamlet } \\ & \text { and made it a representation of the Renaissance spirit and man. Anton } \\ & \text { Chekhov, on the other hand, in his full- length plays, russified it and made it a } \\ & \text { representation of the Russian life and characters of the intellectuals of the last } \\ & \text { two decades in the nineteenth century. The main point of this work is trying to } \\ & \text { put forward, critically and comparatively, is how the Hamlet- type was } \\ & \text { manipulated by two prominent dramatists, Shakespeare and Chekhov, to } \\ & \text { express their own feelings, intellectual questionings, and artistic concerns. }\end{aligned}$

\section{INTRODUCTION}

It would be quiet pertinent to start with a significant theoretical statement that paves the way to discuss the fundamental question which this work is trying to raise by returning to the beginning of the literary type of Hamlet. As Jacques Derrida (1987) has aptly argued:

[...] translation practices the difference between signified and signifier. But if this difference is never pure, no more so is translation, and for the notion of translation we would have to substitute a notion of transformation: a regulated transformation of one language by another, of one text by another. We will never have, and in fact have never had, to do with some 'transport' of pure signifies from one language to another, or within one and the same language, that the signifying instrument would leave virgin and untouched. (p. 20)

Shakespeare and Chekhov creatively used, adapted, or transformed a historical extant literary type of Hamlet according to the artistic traditions, intellectual principles, and the theatrical means of their epochs. Shakespeare used the character as a representation of the Renaissance man, and the play as a symbol of the impact of the Renaissance on English culture. Shakespeare anglicized the type but Chekhov russified it. Hamlet has exerted an appreciable influence on the Russian imagination, so that one can indeed talk about the Russian Hamlet as a literary or dramatic phenomenon. Hamlet has actually been involved 
with Russian life and culture for more than two centuries. Writers have continuously employed the melancholy prince to explore or express their own feelings, intellectual questionings, and socio-cultural concerns. Shakespeare's play has quite often been the mirror held up to Russian life, and as life changed, so did the function of the drama and the image of the prince.

Throughout its history in Russia, Hamlet has had a vital political, social, and cultural importance. Aspects of its plot resembled the circumstances attending Catherine's assumption of power. The play was regarded as a favorable comment on the succession of Alexander I. During the repressions of Nicholas I, it appeared to give vent to the expression of frustrated feelings. Hamlet's ability to discern evil and falsehood and to give strong expression to his responses was prized by Mochalov's audiences and by Belinksy. This kind of Hamletism substantially began with Mochalov's performance in 1837. Mochalov's romantic and gloomy Hamlet started the trend of identifying oneself or others as "Hamlet" and treating the character quite apart from the context of Shakespeare's drama.

\section{DISCUSSION}

In the 1830s and 1840s, Hamletism was associated with introspection and a highly valued capacity for great, noble feelings; consequently, it indicated a tendency to think too much; it became identical with weakness of will and inability to act, as well as a tense preoccupation with this very inability. Hamletism also became a pose masking mediocrity and a lack of real substance. For civic critics, it came to represent social and political stagnation. Chernyshevsky used the label 'the Russian Hamlet' as a synonym for the famous term 'superfluous man'. Later, Hamlet came to dominate the Russian consciousness in nineteenthcentury literature more than any other literary figure. Russian writers used Hamletian allusions to heighten a literary or dramatic effect or convey a political, moral, or artistic message. For example, Pushkin, Gogol, and Tolstoy attributed to Hamlet qualities which characterize their own protagonists, unequivocally related their heroes to Hamlet, or identified themselves with Hamlet - most notably, Lermontov, Dostoevsky, Turgenev, and Chekhov. However, Chekhov wrote at the end of the nineteenth century literary tradition of Hamlet in Russia. Like all Russian writers, Chekhov is steeped in the literature of his own country. The Chekhovian play is a natural and consistent development of a tendency dominant in the Russian theatre and the novel to focus attention less on plot than on portraiture, psychology and ideas.

The directness of Chekhov's realism is accompanied by symbols, sounds, and a whole range of non-verbal devices to add unexpected dimension to the simple prose of everyday life. Chekhov used literary allusions, and he quoted not only from Russian literature, but also from that of Western Europe. The first and most evocative of such allusions are those taken from Shakespeare's Hamlet. These allusions constitute a whole network of themes, images, and echoes that make his plays comparable with that of the English playwright. In different ways and measures, each of his plays is concerned with the themes of usurpation, unreciprocated love, suicide, madness, or with the melancholy, ineffectuality and indecision of its main characters. More specifically, the literary ghost haunting Chekhov's portrayal of his feckless, inadequate, overpowered, and irresolute characters is Shakespeare's hero, Hamlet.

Almost all men know the character Hamlet, even those who have never read the play or seen it performed. There is some trace of Hamlet somewhere in the human collective consciousness which makes him familiar. Hamlet is a living amalgam of influences. Artistically and critically, the play is an accumulation, compound of different values, 
conceptions, contradictions, delivered to modern sensibility, itself as complicated and contradictory as the character. T. S. Eliot wrote:

Hamlet is a stratification that represents the efforts of a series of men, each making what he could out of the work of his predecessors. The Hamlet of Shakespeare will appear to us very differently if instead of treating the whole action of the play as due to Shakespeare's design, we perceive his Hamlet to be superposed upon much cruder material which persists even in the final form. (1932, p. 142)

Just as old literary works are, as it were, rewritten from a modern perspective, so Shakespeare rewrote and reshaped the popular narratives of his day, using Holinshed, Boccaccio, Surrey, Kyd and Marlowe for his own purposes. All dramatic writing is technically a perpetual transformation of other texts. What is true of a poem is true of a dramatic work; Terry Eagleton writes: "Every text is a set of determinate transformations of other, preceding and surrounding texts of which it may not even be consciously aware: it is within, against and across these other texts that the poem emerges into being" (1977, p.73). The transformation in Shakespeare's case produced exceptional creations, "a synthesis and perfection of all the elements which had preceded him" (Markowitz 1986, p. 15).

Yet with time, even that perfection needs to be reworked and vitalized again in accordance with the criteria of a new age. What happens here is that the classic is "declassified", "historically adapted" (Lukács, 1962, p. 155), ${ }^{(1)}$ and rewritten, redressed or "abducted" as Andre Lefevre has remarked in this respect:

A poetics, every poetics, always leaves room for what Peirce calls "abduction" as opposed to induction or deduction. Abduction implies both knowledge of the poetics and the ability to alter that poetics in such a way that those confronted with the alteration will at the same time recognize both the alteration and the poetics. When Cervantes subjected the romance of chivalry to the process of abduction that would eventually result in Don Quixote, his first readers derived pleasure from the contrast between the abduction and the poetics. Similarly, on a more formal level, the abduction Shakespeare subjected the Italian sonnet to still bear his name today. A series of abduction, or one highly successful abduction, may result in a change of the poetics, but a change in which the original poetics still remains visible in the background. (1987, p.129)

Both Shakespeare and Chekhov transformed, or adapted or 'abducted' a historical extant literary type of Hamlet in accordance with the level of development of artistic laws, tastes, conception and resources of their own times. Shakespeare, familiar with the Seneca style, and visualizing its potentialities as raw material capable of further refinement, must have cast around for a suitable literary type to develop. ${ }^{(2)}$ It seems that he found it in the Hamlet story, then current in the form of a play (now lost) and a version in French (still existing). The story can be found in the folk literature of Iceland, Ireland and Denmark. The Danish historian Saxo Grammaticus put it into its first known literary form. The Legend of Hamlet (called Amleth in Saxo) appears in the third and fourth books of the Historia Danica (Danish History), a work finished probably early in the thirteenth century, but not printed until 1514 .

Later, in the sixteenth century the story from Saxo was translated into French by Françoise de Belleforest as an item in his collection Histories Tragiques (Tragic stories), 
Volume 5 (1570). This version of the Amleth story was translated into English in 1608 as The Historie of Hamblet. Françoise de Belleforest complicated the characters, relationships, supplied moralizing comment and his version is much longer than that of Saxo Grammaticus. ${ }^{(3)}$ It appeared after the latest possible data for the production of Shakespeare's Hamlet, and cannot therefore have been one of Shakespeare's sources. And since it is very doubtful whether any earlier translation existed, we can assume that Shakespeare got his story either from the original French or from the lost earlier play of Hamlet, which was itself based on the French version of the story.

This lost Elizabethan play, called the $U r$ - Hamlet, may well have been written by Thomas Kyd (1558-94), the author of a very successful revenge play The Spanish Tragedy (c. 1589). Whatever its authorship, the Ur-Hamlet was written by 1589 and was performed in the 1590. There is a reference to it made by Thomas lodge (1557-1625) in 1596 that shows it contained a ghost, for Lodge described the ghost as crying so miserably in the theatre 'like an oyster- wife, Hamlet, revenge'. ${ }^{(4)}$ T. S. Eliot suggests:

What this play was like we can guess from three clues: from The Spanish Tragedy itself, from the tale of Belleforest upon which Kyd's Hamlet must have been based, and from a version acted in Germany in Shakespeare's lifetime which bears strong evidence of having been adapted from the earlier, not the later play (142).

Shakespeare does not follow Saxo's story closely. For example, he changes the names of all the characters. Yet, there is a King in Saxo's history who is murdered by his brother; the brother ascends the throne and marries the dead King's widow. (Her name in Saxo is Gerutha). Her son, Amleth, plans to take revenge on his uncle, and to protect himself he pretends to be raving mad. The king is suspicious, and tries to find out whether the madness is general. It is arranged that Amleth should be spied on by a beautiful girl. He is also spied on as he talks to his mother, and finds the spy (a court adviser, 'fuller of assurance than wisdom') hidden in the straw which lies in the room; he kills him and brutally dismembers the body. $\mathrm{He}$ then tells his mother he will pretend to be mad so as to get his revenge and in this his mother promises to help him. Amleth is sent in exile to England, but by changing the letters he carries to the king of England (they are carved on wood), he manages to get his two companions killed in his place.

After being away for a year, he returns in disguise, makes the courtiers drunk at a funeral feast intended to celebrate his death, sets fire to the palace, and kills his uncle with the sword. He succeeds to the throne and after warlike activities dies in battle. ${ }^{(5)}$ Shakespeare apparently follow this source closely. But the source itself is crude in style and content. In one place, for example, Amleth pretends to be a cock and come into the room flapping his arms as if they were wings. The court adviser, the original of Polonius, is killed and dismembered, and the part of his body are boiled and fed to pigs. And the main motive was simply a medieval revenge motive. Shakespeare's refinements change and modernize the whole nature of the story. J. Dover Wilson writes about this innovation:

Shakespeare no doubt took what he fancied from the old play over which he worked, and glanced now and again into Saxo or Belleforest; but to make him out a deep student of Danish history and customs is absurd. Hamlet is an English prince, the court of Elsinore is modeled upon the English court, and the Danish constitution that of England under the Virgin Queen. (1962, p. 28) 
Shakespeare's use of intellectual concepts belonging to the end of the sixteenth century is obvious in his manipulation of the old play. Whitaker explains:

When Shakespeare went to work upon the old Hamlet play, he was obviously master enough of his craft as a playwright to retain all its theatrical effectiveness and make it even more thrilling. That is obvious to anyone who sees a good performance of Hamlet. But Shakespeare also wrote into the play a tremendous body of ideas - so many, in fact, that Hamlet seems one of the most intellectual characters in all literature. (1965, p. 185)

Shakespeare molded this material into a dramatic form to suit and exploit the resources of a stage different from ours, the Elizabethan. G. K. Hunter discusses Shakespeare's creative transformation of the Hamlet story:

Hamlet is placed unambiguously in a modern age: he was educated at a new university (Wittenberg), lives in a specific extant castle (Elsinore) and is a connoisseur of modern plays and modern fencing ... Yet not only is the original source story in Saxo Grammaticus's History of the Danes as mysteriously antique as that of King Lear and as barbarously northern as that of Macbeth, but Shakespeare's play itself embodies that alien archaism as its central motivating cause. The ghost of Hamlet's father, clanking medieval armor, fresh from a world in which national destinies were settled by personal combat, demands not only that the play embody his cry for revenge but that the ethic of his revenge take over the thinking of his modernist son ... (1986, p.139)

In such a way a Shakespearian text is used to convey a contemporary state of mind in a way that reinforces the new conception and simultaneously reflect the old. A significant characteristic of a classic is that it can be made to carry new meaning when a society no longer thinks the way its author did at the time of writing. ${ }^{(6)}$ Hamlet, however, is a very special case. It is the most often performed, the most widely read, the most thoroughly studied of Shakespeare's plays. ${ }^{(7)}$ Hamlet has become virtually a myth.

Compounded of many diverse views, Jan kott observes: "Many generations have seen their own reflection in this play" (1974, p. 129). Then, he likens Hamlet to "a sponge" which can absorb "all the problems of our time" (Kott, p. 47). Schofield also says: "Modern man can be identified with Hamlet in very many ways" $\left(1980\right.$, p.3). ${ }^{(8)}$ The relatedness to modern man is in the play, but not apparently demonstrable because the play is confined in its narrative. The play is the story, and to present or rewrite the play is to retell the story. New and different interpretation can be expressed by dramatising the narrative in a particular way. ${ }^{(9)}$ It is however the narrativeness, the closed cycle of story-lines, which constricts the power and suggestiveness of what the play has become. When the narrative sequence is broken, one has direct access to the play's essence. One thus can rework a character, or situation, or idea, to signify something. Donaldson states in this respect:

Drama may seem, especially in the modern world, to be one of the most international of all art forms, freely travelling across national and cultural boundaries. Yet plays also obviously undergo a variety of changes, linguistic and otherwise, as they pass from one social context to another, and as time brings about its own changes in social and political perception and expectation... (1983, p. vi). 
For centuries, the nobility of Hamlet as artistic type has been contrasted with the man himself. It is possible for a man to make eloquent speeches and still be a weakling and a coward, to have intellectual perception and moral insights and still be passive and ineffectual. If we remove the romantic aura that surrounds Hamlet, the Renaissance prince, and look at the type in the social and intellectual context of contemporary times, the keynote is considerably modern. The influence of Hamlet is indeed spread throughout modern plays. Thus, the main task behind the present undertaking is to discover to what extent one can alter particular artistic elements and still maintain contact with what is essential in the classical work.

The essence of Hamlet is not to be found in the Historia Danica, or in the Histories Tragiques of Francois de Belleforest, or in Kyd's Spanish Tragedy, but in myths so embedded in human consciousness that no one can trace them to any one source. ${ }^{(10)} \mathrm{H}$. Watts makes an analogy between cyclic and linear myth on the one hand and comedy and tragedy on the other. He alludes to comedy as the cyclic assertion of existence; tragedy, he adds:

Lies inside each man, in his experience of choice, of sequence... The essential - we should observe when we watch Hamlet or Oedipus as well as when we savour the impact of the Christ -story-lies inside each man; it lies in man's experience of a horrid, sheerly linear necessity which no man, once he is aware of it, is ever able to evade. This is the necessity of choice; it is a necessity that gets no comforting "moral support" form the phases of the moon or the return of the season. Each human choice, at a certain time in a non- repetitive sequence of events, projects into future time only a certain portion of the past; each choice denies to the future significant developments of other portions of the past. This is human choice, it is also existence conceived in a linear fashion. $\left(1968\right.$, p. 128) ${ }^{(11)}$

It is because Hamlet is essentially mythical one can weave so many variations on its theme. Shakespeare's play is itself an English variation of one of several of those legends that exist in every nation's sub-culture. Shakespeare, in his inspired and eclectic way, was using different strands of the same story, unavoidably mixing mythic sub-texts by rewriting older material. It is that mixing of myths or versions that produced in Hamlet that "emotion", which is "inexpressible, because it is in excess of the facts as they appear" (Eliot as quoted in Watts, p. 128). In all likelihood, by the time the story reached Shakespeare it was just a story, equal to fairy-tales, anecdotes, or ancient parables. Shakespeare, in his rewriting of the Hamlet story, builds in a new set of tensions and conflicts derived from his own time and possibly his own life. The older tensions and conflicts, the ones deep-rooted in the myths on which the stories are based, however, remain to haunt the sub-text and to produce "the intractable material" (Eliot, p. 145). Some critics commented about that: Eliot, for instance, writes: "Hamlet, like the sonnets, is full of some stuff that the writer could not drag into light, contemplate, or manipulate into art. And when we reach for this feeling, we find it, as in the sonnets, very difficult to localise" (p. 143).

Using certain characters, episodes, or ideas, or a cut - up version of Hamlet, it can be argued, my have not much to do with the play Shakespeare wrote, even if it does utilise many of his words and ideas. One may just as readily ask to what extent Shakespeare can be counted the author of a play which is compounded of ancient group myths and cultural transmutation as well as being obviously collected from two or three verifiable, non Shakespearian sources. 
When a story is handed down from generation to generation over a period of 400 years, it ends up with a great number of cultural features in it. What matters most is not this transformation in art. As Kiernan indicates:

Art, and drama in particular, is an active agent in the formation of new states of mind and of society. Shakespeare can be thought of in all his work as a preserver, moderniser, transmitter of the values of an older time for the benefit of a later one. ${ }^{(12)}$

Accordingly, it is a question not only to what extent a dramatist is influenced by a classical play, but also how that text is used and changed to say something new to other people artistically and convincingly. Hence, the point which this work is stressing is that each age reconsiders and reinterprets Hamlet, not because this dramatic text changes, but because despite the existence of numerous and reliable editions of the play, there is no such fixed object as Hamlet, independent of its editor, the actors who play its roles, the producers and critics, the script writers or the translators who put it into other languages, the millions of readers who have read it or watched its performance since the late sixteenth century. On the other hand, it is too much to say that Hamlet has no independent existence at all and that it is completely reconstructed every time someone reads, acts, watches, adapts or writes about it. Hamlet leads an institutional or cultural life that among other things has guaranteed its prominence as a great dramatic text, and its exceptional canonical powers at least in western culture. The significant thing here is that even so relatively inert an object as a dramatic text is commonly supposed to gain some of its identity from its historical movement interacting with the concerns, judgements, performances and scholarship of its readers. In this context, Hamlet has exerted such an enduring influence on the Russian creative imagination,that one can speak of a 'Russian Hamlet' as a literary phenomenon. Hamlet, as a character, as a complex of attributes, is vividly present in Russian literature from Pushkin to Pasternak. David Kirby, in an interesting article, "Chekhov's Influence on Shakespeare" writes: "This universal applicability explains why Shakespeare not only inspires others as no other artist has but brings out the best in them" (2004, p. 192).

Critically speaking, the readers' and audiences' perception of Chekhov's transformation of Hamlet influence and can help largely in understanding Shakespeare's version of Hamlet. This reminds us with David Lodge when writing about the influence of Eliot on Shakespeare:

Well, what I try to show", said Persse, "is that we can't avoid reading Shakespeare through the lens of T.S Eliot's poetry. I mean, who can read Hamlet today without thinking of 'Prufrock'? Who can hear the speeches of Ferdinand in The Tempest without being reminded of 'The First Sermon' section of The Wast Land?" (Cesar Dominguez et al, 2015, p. VIII)

George Steiner writes that the image of Chekhov, the author, has entered the English culture and it corresponds to one of the interpretation that the Russians have put upon Shakespeare's protagonist, namely that "of a gloomy and cold man obsessed with the greyness of life" (p. 130). Indeed, irresolution, melancholy, inactivity, introspection, abstract speculation, nostalgia, and decay, all of these characteristics are associated with Chekhov's characters, and even, sometimes with Chekhov himself, especially in his last years when he was dying, and when he is depicted as "a haggard, suffering man who seems to maintain his aloofness even on paper" (Lantz, p. xiii). This is despite the fact that sometimes his letters reflect his humour, gentle self - mockery, and immense charm, and his biographers present him as a man of warmth, gregarious nature and strong social concern. One can explain 
Chekhov's special place in England, for instance, in terms of the English conservatism and reserve, the sense of compromise and thoughtfulness; or if one sees it in Chekhov's ability to rise above national boundaries, the fact remains that Chekhov has become part and parcel of the English theatre. Kirby aptly comments in this connection:

I couldn't help thinking what Shakespeare might have done with Chekhov's play. With rare exception, he derived all his plays from earlier sources, which he then complicated, sometimes beyond recognition. At the very least, he would have added several plot lines to Uncle Vania as well as the necessary new characters to flesh them out and also up the pace. (p. 177)

Thus, through opposite influence, his 'Russian Hamlet' emerges as another manifestation of his talent for borrowing ideas from English authors, transforming them, and then sending them abroad. William Morris wrote, in March 1888, after reading Tolstoy's War and Peace, "Hamlet (Shakespeare's I mean, not the genuine Amlot) should have been a Russian, not a Dane."(13)

Not only has Hamlet been the most popular and influential of Shakespeare's plays in Russia, but as Morris Valency remarks the main character has "realised for the Russian mind a psychic posture that was more familiar, and much more acceptable, than that of Lermontov's Arbenin or Byron's Manfred" (1965, p. 280). For more than two centuries, Russians have felt a closeness to, and fascination for, the despondent prince. Kartoschinsky states that "it was Hamlet that won the deepest sympathy of the Russians. His passivity, his constant reflection, his everlasting pensiveness - are these not typically Russian traits? we can almost say that in Russia alone Hamlet is sincerely loved and deeply understood" (1916, p.143). Intellectual concern, philosophical tendency, emotional involvement, and subjective identification with Hamlet are reflected to the full in Russian literature. One critic has gone so far as to observe that "Shakespeare's spirit" came to be "transfused into Russian literature and the mind of Russia, where the note of philosophical fatalism in Russian novel after Russian novel was derived finally from Hamlet" (Brewester 1954, p. 218).

Toward the end of 1901 three great Russian writers met at Yalta. Each was there for reasons of health, and their meeting had not been prearranged. As Muchnic (1963) writes: "in retrospect this meeting seems an epitome of changes that were taking place in the thought of the country, of major trends in its intellectual history. It was a little drama of Russian letters at the turn of the century" (1963, p.3). The writers were Tolstoy, who was seventy- four years old; Chekhov, who was forty-two, and Gorky, thirty-three. In them three epochs met, three modes of thought and writing, and three classes of society. Social and political stagnation followed the assassination of Alexander II, who had freed the serfs, and the accession of the reactionary Alexander III in 1881. Dostoevsky died that year, Turgenev in 1883, and Tolstoy had turned away from belles letters. The deep and considerable religious and moral explorations which had so dominated the works of Dostoevsky and Tolstoy were not the primary concern of Anton Chekhov (1860-1904).

The literary Russian tradition does account for Chekhov's conception of Hamlet. Donald Rayfield notices that in the nineteenth century: "Hamlet had become an honorary Russian citizen in a dishonourable Russian predicament. His failed duty to the state and Ophelia mirrored the failures of Russian intellectuals and Russian "superfluous men" (Muchnic, p. 3). Chekhov's idea of Hamlet was coloured by Turgenev's view, and many of his dreamy characters are often reminiscent of Hamlet at his most melancholic and self- 
analytical. Chekhov was fascinated by the Hamlet-type; and as Donald Rayfield puts it: "Hamlet infects all of Chekhov's plays, from Ivanov to The Cherry Orchard" (p.44). Chekhov had, however, a great respect for Shakespeare. His first 'vaudeville', "Kalka's" (1887), contains, among many excerpts lifted without alteration from the dramatic repertoire of the Russian stage, excerpts from King Lear, Othello, and Hamlet (p. 44). The Hamletian allusions and references in the short stories and plays are too many to cite. It is said that Chekhov's letters contain more allusions to Shakespeare than to all other literary classic put together. There is no evidence however that Chekhov read Shakespeare in English, though in his notes and letters he refers admiringly to the Shakespeare translations of Peter IsaevichVeynberg (1830-1908). ${ }^{(14)}$ References to Shakespeare's Hamlet can be found widely in Chekhov's works.

Eight new translations of Hamlet appeared between 1878 and 1900; those of P.P Gnedich and K. R. (Prince Konstantinovich Romanov) were especially important. However, nor could any reference to Chekhov's knowledge of the original be found. "I can't read English" he declared on 9 August $1900{ }^{(15)}$ Chekhov's letters, and note-book, display his constant preoccupation with this play. However, the only criticism that Chekhov wrote of a Shakespearian play was in his review of a popular performance of Hamlet as early as 1882 in the Pushkin Theatre in Moscow. ${ }^{(16)}$ While criticizing what he considered the misrepresentation of the character of Hamlet by the actor Ivanovo - Kozelsky, he expressed strong praise for the play and its author, voicing the hope that Hamlet would help in the need to revitalise the Russian stage, even if played in mediocre fashion. "Better a badly acted Hamlet, than boring emptiness", he proclaimed. Hamlet, he said, had been represented as a whiner, especially in Act 1, although "Hamlet was incapable of whining. A man's tears are valuable and must not be wasted on the stage. Mr. Ivanov Kozelsky", Chekhov complained, Hamlet "was frightened of the ghost, so much so that one even felt pity for him... Hamlet was a man of indecision, but he was never a coward."(17) This view of Hamlet as a relatively strong personality is important in considering the development of the image of Hamlet in Chekhov's works. In 1882, Chekhov also published a sketch, "The Baron", featuring a performance of Hamlet. Both the review and the sketch reflect one early idea of Hamlet who has courage and strength. However, most of Chekhov's uses of Hamlet display a decisive Turgenevan influence. Chekhov was indeed acquainted with Shakespeare's play and Turgenev's essay on "Hamlet and Don Quixote" at an early age. ${ }^{(18)}$

In the sketch "In Moscow" (19) (1891) the speaker who calls himself "a Moscow Hamlet" may be seen to bear a similarity to Turgenev's Hamlet of the Shchigrov District. As the protagonist in the latter suffers because of his lack of forthrightness and originality, so Chekhov's Moscow Hamlet reveals his psychological bankruptcy and sheer boredom. He is oppressively bored because of his real lack of knowledge and culture, an inflated idea of his own cleverness and importance, and his furious boundless envy. He finds his brand of Hamletism contagious: as he complains of his boredom, looks important, and slanders his friends and acquaintances, he observes a young student solemnly imitating him, making cynical remarks and exclaims "Words, words, words... God, how boring!"(20) He shows pretentions to erudition and assumes an air of general dissatisfaction. Yet he could- have learned, achieved and contributed to the general welfare, he adds: "But I am a rotten rag, useless rubbish. I am a Moscow Hamlet" (Chekhov, p. 348).

The idea of suicide as the hero's only solution haunts the whole narrative. It may be maintained that Chekhov's own interpretation here was not limited to Turgenev's view. His Moscow Hamlet appears to have the mediocrity of Turgenev's Shchigrov Hamlet, but also the 
malice of Dostoevsky's Underground Man. Yet, he lacks the latter's depth and perverse exultation. So, it is clear that the negative qualities associated with the Hamletism of the sketch are used by Chekhov to analyze and reveal some of the basic characteristics of the Russian intellectual. The main characteristics of the sketch in relation to Chekhov's use of Hamlet, unlike his mature dramatic work, is that his own judgment is made explicitly. In his major plays, there is a fine balance, objectivity, and no easy value judgments. In The Duel (1891), Laevsky, weak and demoralised, finds consolation in a flattering comparison, "I'm as bad as Hamlet... How neatly Shakespeare hit him off - how very true to life."(21)

It can be said that some of the negative characteristics which had come to be linked with the name Hamlet are used also by Chekhov so as to consider some essential aspects of the human condition. As Yarmolinsky has said of Chekhov: "Notwithstanding his protestations of objectivity, there is indignation and indictment in his pages, a thinly veiled criticism of life" $(1969$, p.110). Yarmolinsky also finds "implicit in his writings" a judgment "against cruelty, greed, hypocrisy, stupidity, snobbery, sloth - all the slavish traits he had been at pains to squeeze out of himself, against whatever degrades man and prevents him from achieving his full Stature" (p. 109). This is rendered in a slightly different way by Ronald Wilks, "I'm just like Hamlet in my indecision! How truly Shakespeare observed it! Oh, how truly" (Chekhov, The Duel, p. 29).

Although a characteristic Chekhovian tone of gentle irony may be read here, we do not feel that Laevsky is ridiculed for identifying himself with Hamlet. Laevsky, however, possesses most of the qualities of Chekhov's Russian Hamlets; in the words of his strong German foil, Von Koren: "he's an intellectual, a liberal, a university man. He's also a failure, Superfluous Man, a neurotic, a victim of the age... " (The Duel, p.39).

Platonov, the protagonist of a play by that title, Chekhov's first play, written between 1881 and 1884 and unpublished in his lifetime ${ }^{(22)}$, also compares himself with Hamlet. In one of the last scenes he picks up a revolver, resolves to kill himself, and exclaims: "Hamlet was afraid of dreams. I'm afraid of - life" (Chekhov, The Oxford, p. 144).Yet then he decides in his weakness to live after all. Magarshack views the significance of the play in its being the "repository of themes and characters he was using in his later plays" (Chekhov, The Oxford, p. 144). He also sees the Hamlet quotation in The Seagull and The cherry orchard as "an echo of the quotations in Platonov, except that in the two later plays their invocative implications are much more subtle" (Chekhov, The Oxford, p. 150). The drunken Voynitsev, unconscious that he is about to lose his wife, Sophia, to Platonov, tells him his idea of staging a performance of Hamlet: "I shall play Hamlet, Sophy - Ophelia, you - Claudius, Triletsky Horatio". ${ }^{23)}$ Voynitsev also implies that his mother, whom he know to be romantically involved with Platonov, will play Gertrude. Then he quotes Hamlet's words to Gertrude: "0 shame! Where is thy blush?" (Chekhov, Platonov, pp.131-32) Platonov, apparently struck by the appropriateness of these words, runs off. Voynitsev leaves too' quoting: "Ophelia, nymph, in thy orisons be all my sins remembered" (Chekhov, Platonov, p. 91).

In The Wood Demon (1889), the early unsuccessful version of Uncle Vania, Dyadin, a type of saintly fool to whom everything is "delightful", quote: "There are more things in heaven and earth, Horatio, than are dreamt of in your philosophy!" (Chekhov, Platonov, p. 132). This quotation was a favourite of Turgenev. The idea that Chekhov used it for humourous purpose is indicative of the change in the times and the difference in their temperaments. 
Chekhov actually employed Hamlet in all his full- length plays, from Ivanov to The Cherry Orchard. It may be said that if one speaks of Hamletism here, it is Hamletism with a tragic significance and of a mature kind: Hamletism that represents an endeavour to achieve a peculiar philosophy of tragedy in modern drama at the end of a critical epoch. Chekhov, the medical scientist and the realist artist "diagnosed his nation's ills" and came to depict the tragedy of the Russian Hamlet, "the middle-class intellectual of a transitional period" (Muchnic, pp. 1-5).

The first attempt to resist the standard use of the Hamlet image is embodied in Ivanov (1887-1889). Three direct allusions to Hamlet can be seen in the play: in the second act, Ivanov addresses Sasha: "I'm dying of shame at the thought that I, a healthy strong man, have somehow got transformed into a sort of Hamlet, or Manfred, or one of those "superfluous" people, the devil knows which!..."; in the third act he makes another allusion to Hamlet: "... You seem to think that you've got hold of a second Hamlet in me"; and in the final act he acutely replies Sasha: "I've acted Hamlet and you've acted a high-minded young women- we can't go on like that." ${ }^{(24)}$ Despite the fact that Ivanov the protagonist, in these allusions, tries to distance himself from being identified with Hamlet, emerges mainly as a tragic figure, "the Russian Hamlet of the eighteen eighties." (25) He appears as romantic figure which does frequently recur in Russian nineteenth-century literature, that is, the archetype that came to be known as the 'superfluous': the tortured intellectual and idealistic man who is incapable, for reasons as complex as Hamlet's of engaging in effectual action.

Chekhov has created through Ivanov a typical figure of his own time and one which echoes the so-called 'superfluous people' of the previous decades. This figure is particularly relevant to the decade of the 1880s. This was a time of political reaction and repression - for the intellectuals, a period of disillusionment and despair-and Ivanov seemed a spokesman for a world a world-weary generation. Although Ivanov was too honest and did not wish to be a Hamlet, yet he becomes one: a Hamlet figure with all the qualities necessitated by his age. In the later plays there is always a deep reason in Chekov's complex attitude to Russian Hamletism and to the kind of figures who are represented by Ivanov, ranging from Platonov to the characters of The Cherry Orchard. Chekhov's intent and dramatic can usefully be investigated through a chronological analysis of the Hamletian characters and evocations in the plays.

Hamlet is related to the total structure of The Seagull, and the image of Hamlet is connected with the ideas, situations, and characters of the play. The relation creates a whole programme of references and suggestions through which Chekhov's play achieves a specific meaning. ${ }^{(26)}$ Employed Hamletian quotation and scenes are there primarily for their obvious suitability in heightening dramatic effect and enriching the text. The dramatist drew upon the full context of the Hamlet allusions with the additional effect of creating often, a distinct tragic sense. He absorbed Shakespeare's text - because of his affinity with the feelings and ideas he found expressed therein - that the Shakespearian words came to him whenever they seemed related to the specific emotional or intellectual context he was putting forward. Whether or not The Seagull's characters and themes follow the characters and ideas of Hamlet, they are linked to Shakespeare's play in a way to suggest a contemporary Russian portrait.

The weakness, inadequacy, despondence and loneliness of Trepliov is accentuated by the reflection, inactivity and melancholy of the Shakespearian hero - Chekhov's use of Hamlet, goes beyond its significance for the Russian Hamlet, Trepliov, alone, though this 
figure is central in the work. Trepliov in his relation with Arkadina, Trigorin, Nina, and Dorn recalls that of Hamlet's with Gertrude, Claudius, Ophelia, and Horatio. In The Seagull, usurpation is that of the world of art, yet Trepliov's frustrated endeavours to contest with Arkadina and struggle to replace Trigorin, reaches to a deeper level of the theme: the usurpation by art of life itself. Chekhov used Hamlet's remark "Denmark's a prison", as he did in Ivanov, and associated it with Sorin's estate. Within the context of this metaphor, the horses come to symbolize escape from boredom and the spiritual confinement of the estate.

In his plays, Chekhov always appears to be indicating that the real issue is not 'interest' but 'exposure'. The protagonist of Shakespeare's play shows negative qualities, but he remains a sympathetic character. Chekhov's Russian Hamlets show similar, yet deeper ambiguity. The question of where Chekhov's attitude lies, although it is clearly presented and he showed more concern towards his Hamlets, is not unambiguously answered. Does it lie with the usurpers of the estates or the spheres of art, knowledge and social hegemony? Or does it lie with those who seek to replace them? These are often seen to reflect the artistic and intellectual debate going on within Chekhov himself.

A kind of ambiguity extends also to include Chekhov's dramatic form of tragedy. This has led some critics to argue that the plays are tragi-comedies, and others to take Chekhov at his word and follow his description of the plays as comedies. It is difficult however to interpret the drama of Chekhov in terms other than those of the plays themselves. Like Shakespeare's Hamlet, they, especially his last three plays, appeal to human life in its various aspects; use comic episodes and characters, and prove the principle that unmitigated tragedy is out of place in this life. In the plays, Chekhov transformed the situation of a tragic deadlock into a new condition, that of a stalemate, where there is no possibility of movement at all for the wrestler with life, every willed action is self - cancelling. Shakespeare could not resolve in action or do anything about Hamlet's dilemma except express it with great realism. Chekhov similarly could not resolve the stalemate of his characters; he could do nothing about their situation except present it with profound realism. Chekhov tried to "hold the mirror up to" the Russian life he knew and to reveal that "something is rotten" in that life; the plays therefore stand as "the abstract and brief chronicles of the time".

Inertia, boredom, weariness, dissatisfaction, despair and other Russian features represented by Chekhov's characters, amalgamated with Hamletian 'nonaction', melancholy, intellectualism, constitute the temperament of Russian at the end of the century. These traits are the personal and psychological indications of declining social groups: estate owners, intellectuals, idealists, doctors, students, and servants. Those indications allow the transformation in the drama from the so-called 'superfluous men 'to the 'superfluous nation'. Hamlet, as a literary figure, remained very close to the soul of last two decades of the nineteenth century. The type is adopted by Chekhov to investigate and display the problem of the Russian intelligentsia. Ivanov shows essential characteristics of Chekhov as a mature dramatist. Characters in Chekhov's subsequent plays like Trofimov can be compared with Ivanov either in their ineffectuality, indecision, idealism, exhaustion or inability to cope with reality.

Uncle Vania and Three Sisters make no direct reference to Hamlet. However, usurpation of the estate and the realm of knowledge, a Hamletian echo, appears as a central idea in Uncle Vania. The situations and predicaments of its characters are fundamentally Hamletic, especially those of Voinitsky. Three Sisters also compares extensively with Hamlet; as a drama of indecision and insoluble question, about three sensitive intellectuals, 
unable to act or come to terms with reality. And the theme of usurpation becomes finer in this play. Moreover, the metaphor of the estate as prison, together with horses or birds signifying escape to freedom, recurs in Uncle Vania and Three Sisters.

In The Cherry Orchard, the theme of dispossession and the significance of the image of the estate, with its cherry, do not disappear, but they assume deeper and wider social and political Russian dimensions. The influence of Hamlet on The Cherry Orchard is, however, explicit. Lopakhin quotes Hamlet, and the story of the play revolves around the fate of the superfluous inhabitants of Ranyesvkaia's estate and their Hamletic efforts to save the orchard. The textual and contextual relationship between Hamlet and Chekhov's plays is strengthened by an important socio- political factor. History later showed that Shakespeare's and Chekhov's dissatisfaction was founded, and proved that both artists were in advance of their own times. Finally, it may be relevant to cite Kirby's conclusion on this issue: "if it's true that all roads lead to Shakespeare, it's equally true that Shakespeare leads to all roads" (p. 193).

\section{CONCLUSION}

This work tried to explore the use of the type of Hamlet through the perspectives motivated by Shakespeare's and Chekhov's responses to Hamlet. The story of Hamlet had an immense influence on both playwrights. It has focused on the idea of dramatic transformation, with reference to translation; influence, adaptation, transmission, and abduction, in order to show that Shakespeare made the aforementioned type a representation of the Renaissance man and Chekhov a Russian type of late nineteenth century intellectuals. Their versions of Hamlet testify to their dramatic talents in addressing different audiences at different times and in different centuries. This paper has found out that, unlike ordinary literary types, Hamlet bears the potential to be put to use by different authors throughout the ages to express subjective processes and various universal values. The significance of the study has stemmed from its being one attempt in a long critical tradition produced on the Hamlet industry. It is also one critical and comparative attempt in studying Hamlet with reference to Shakespeare's and Chekhov's conceptions of the type. The critical and comparative outlook pursued the idea of transformation taking the views of a number of critics and writers into consideration to spotlight Shakespeare's and Chekhov's rewriting of Hamlet.

\section{NOTES}

1. George Lukács, The Historical Novel (London: Merlin Press, 1962), p.155. Lukács has observed that: "it would be quite wrong to view Shakespeare's adaptation of legendary material as a form of "modernization" in the modern sense... critics who consider that the Roman plays, written concurrently with the great tragedies, really portray English events and English characters and simply use the ancient world as costume... But in judging these plays what matters is precisely the generalizing nature of Shakespeare's characterization, the extraordinary breadth and depth of his insight into the various currents forming the crisis of his period. And the classical world is a living social-moral force in this period; it is not felt as a distant past to which one has to reach back... he does not simply inject the spirit of his period into the ancient world, but rather brings to life those tragic events of antiquity which were based on historical-moral experiences inwardly similar to those of his own time; so that the generalized form of the drama reveals the features which the two ages hold objectively in common." See, ibid., pp.155-6.

2. Hamlet has been described as an exercise in the English Seneca, "what Kyd inherited form Seneca makes a very imperfect play. Shakespeare utilizes his inheritance to create a first class 
tragedy". See, B.L. Joseph, The Spanish Tragedy and Hamlet: Two Exercises in English Seneca", in Classical Drama and its Influence, edited by M. J. Anderson (London: Methuen, 1965), p. 134.

3. For more details, see, "The Source of Hamlet" in William Shakespeare, Hamlet (Beirut: York press, 2009), pp. XXVI-XXVIII.

4. See, ibid, p. XXVII.

5. See, William Shakespeare, "Introduction" to Hamlet, edited by Bernard Lott (London: Longman, 1981), pp. xix-xxi.

6. Some contemporary successes have been derived from the acknowledged masterpieces, for example, Edward Bond's Lear (1971), Eugene Ionesco's Macbeth (1972) and Heine Muller's Macbeth (1971) and Hamlet Machine (1977). Frederic Durrenmatt chose early and relatively minor plays for his adaptations Konig Johann (1968) and Titus Andronikus (1970). For a discussion of the prevalence of Shakespeare's inventions in western culture, the transpositions from Hamlet, the experiment of Bond's Lear and Ionesco's Macbeth, the legion of "Macbeths “, of " Othellos' " and of "Leers", see, George Steiner, Antigones (Oxford: Clarendon Press, 1986), pp. $129-131,235-6,268,301-2$.

7. George Steiner refers to Hamlet's place in western culture: "The staple rejoinder is that the western imagination after Christ has also generated archetypal personae and plots which possess the self- replicating drive of antique mythology. Four are cited: Faust, Hamlet, Don Juan, Don Quixote. They are, to be sure, very different in origin and after-life. Hamlet and Don Quixote appear to represent specific acts of authorship, of particular contrivance. Their sources of being, most evidently with regard to Cervantes', novel, are local and historical. Both have crystallised and, in turn, perpetuated certain stances, "typologies", self-recognitions, mimetic styles, in western sentiment and behaviour 'Hamlet ', 'Don Quixote' are familiar encodings of idiom and gesture throughout western society since the seventeenth century. And both have, of course, led multiple lives in art, music, drama, ballet and film".

8. Martine Schofield sums up the whole point about the play, "it is a mirror in which every man has seen his own face". The Ghosts of Hamlet (Cambridge: Cambridge, 1980), p. 3.

9. George Stiener, Antagonies, p. 52.

10. See, Ian Donaldson, Transformations in Modern European Drama (London: The Macmillan Press, 1983), p. vi.

11. For Hamlet as a literary myth, archetype or symbol, see, J. E. Cirlot, A Dictionary of Symbol, translated by Jack Sage (London: Rutledge and keg an Paul, 1984), p. 136; and for the Hamlet story as a nature-myth see, Add De Varies, Dictionary of Symbols and Imagery (North-Holland Publishing Company, 1976), p. 235.

12. For instance, The College (1966), by the author and director, Charles Markowitz, is a condensation of Shakespeare's Hamlet, see, The Markowitz Hamlet, pp. 53-112. The efforts of the actor Maurice Evans (1901-1989) may be mentioned with the so -called G. I. version of Hamlet, and his transformed Lear and Romeo and Juliet; see, Phyllis Hornell, The Oxford Companion to the Theatre (Oxford: Oxford University Press, 1978), pp. 301-2 Jacobs and Johnson count no fewer than fifty-no works burlesquing Hamlet since 1820, see, Henry, E. Jacobs and Claudia D. Johnson, An Annotated Bibliography of Shakespearian Burlesques, Parodies and Travesties (New York: Garland Publications, 1976 ), pp. 19 -31.

13. Among the best of Chekhov's biographies in English are: E. J. Simmons, Chekhov: A Biography (Chicago: The University of Chicago Press, 1970); and Ronald Hingley, A New Life of Anton Chekhov (London: Oxford Up 1976).

14. See, Thomas G. Winner, "Chekhov's Seagull and Shakespeare's Hamlet: A Study of a Dramatic Device "American Slavic and East European Review, vol. XV (February 1956), p. 104. 
15. See, Gordon McVay, "Chekhov in Britain 1988" Scottish Slavonic Review, p. 183.

16. See, Thomas G Winner, "Chekhov's Seagull and Shakespeare's Hamlet" A Study of a Dramatic Device" American Slavic and East European Review, p. 103.

17. Quoted in Thomas G Winner, "Chekhov's Seagull and Shakespeare's Hamlet" A Study of a Dramatic Device" American Slavic and East European Review, p. 103- 104.

18. For a plot summary of "The Baron", see, Eleanor Rowe, Hamlet: A Window on Russia, p. 108.

19. For Turgenev's conception of Hamlet and its impact on Chekhov, see first: Evan Turgenev, "Hamlet and Don Quixote", translated by Leon Burnett, (Colchester: Essex University, 2009); and see also, Chekhov's letter, at nineteen years, to his brother Mikhail Chekhov between April 6 and $8,1879$.

20. This feuilleton was published in No.5667 of the NovoyeVremya, 7 December (1891) under a pseudonym. See, "In Moscow" in Letters on the Short Story, the Drama and Other Literary Topics by Anton Chekhov, translated and edited by Louis S. Friedland (London: Vision Press, 1965). Sometimes it `appears under the title "A Moscow Hamlet", see, S. S. Koteliansky's dictions and translations: Anton Chekhov: Literary and Theatrical Reminiscences (London: George Rutledge, 1927), pp.215-223: and Plays and Stories by Anton Chekhov (London: J. M. Dent,1937), pp.343-349.

21. On December 4, 1891, he wrote to Souvorin that in this feuilleton he had "wanted to depict briefly a Moscow intellectual". He asked Souvorin to keep the secret that he had chosen a new pseudonym for this piece. See, Eleanor Rowe, Hamlet: A Window on Russia, p.123.

22. For an account of the origin of this untitled play, see, Michael Frayne's introduction to, Anton Chekhov, Wild Honey (London: Methuen, 1984).

23. See Anton Chekhov, Platonov, translated by David Magarshack, pp.131-132.

24. See Anton Chekhov, Plays, translated and introduced by Elisaveta Fen (London: Penguine Classics, 1982), pp. 71-93, and 108, respectively.

25. For this designation and further information see, Fuad Abdul Muttaleb, "Chekhovs' Ivanov: A Portrait of The Russian Hamlet of The Eighteen Eighties", Babel Faculty of Basic Eduaction for Education and Humanities- Babel University, No. 27, June 2016, pp. 50- 64. And for more details, see: Fuad Abdul Muttaleb, "Shakespeare's Hamlet, Chekhov's Ivanov and the Creation of Literary Type", New Comparison, 1995, No. 19 pp. 65-79.

26. See, Thomas G. Winner, "Chekhov's Seagull and Shakespeare's Hamlet: A Study of a Dramatic Device "American Slavic and East European Review, vol. XV (February 1956), pp. 103-111.

\section{REFERENCES}

Brewester, D. (1954). East -West Passage: A study in literary relationship. London: George Allen and Urwin.

Cesar, D., Haun, S., \& Dario V. (2015). Introducing comparative literature: New trends and applications. London and New York: Routledge.

Chekhov, A. (1965). "In Moscow" in letters on the short story, the drama and other literary topics. Translated and Edited by Louis S. Friedland. London: Vision Press.

---. Platonov. (1961). Translated by Dmitri Makaroff with an introduction by George Devine. London: Methuen.

---. (1937). Plays and stories. London: J. M. Dent.

---. (1970). The Oxford Chekhov, Vol. V. Translated and Edited by Ronald Henley. London: Oxford UP. 
---. (1982). Plays, Translated and Introduced by Elisaveta Fen. London: Penguine Classics.

---. (1984). The dual and other stories. London: Penguin Books.

Cirlot, J. E. (1984). A dictionary of symbols. Translated by Jack Sage. London: Routledge and Kegan and Paul.

Derrida, J. (1987) Positions. Translated by Alan Bass. London: Athlone, p. 20.

De Varies, A. (1976). Dictionary of symbols and imagery. North- Holland Publishing Company.

Donaldson, I. (1983). Transformations in modern European drama. London: The Macmillan Press.

Eagleton, T. (1977). “Translation and transformation”. Stand, 19 (3), pp. 72-77.

Eliot, T. S. (1932). Selected essays. London: Faber and Faber.

Frayne, M. (1984). Anton Chekhov, Wild Honey. London: Methuen.

Henry, E. J., \& Claudia D. J. (1976). An annotated bibliography of Shakespearian burlesques, parodies and travesties. New York: Garland Publications.

Hingley, R. (1976). A new life of Anton Chekhov. London: Oxford UP.

Hornell, Ph. (1978). The Oxford companion to the theatre. Oxford: Oxford UP.

Hunter, G.K. (1986). "Shakespeare and the tradition of tragedy" in The Cambridge companion to Shakespeare's studies. Edited by Stamley Wells. Cambridge: Cambridge UP.

Jones, E. (1977). The origins of Shakespeare. Oxford: Oxford UP.

Joseph, B. L. (1965). "The Spanish tragedy and Hamlet: Two exercises in English Seneca" in Classical drama and its influence. Edited by M. J. Anderson. London: Methuen.

Kartoschinsky, O. M. (1916). "Shakespeare in Russia”. The Russian Review, 3, p. 141-146.

Kiernan, V. G. (1964). "Human relations in Shakespeare" in Shakespeare in a changing world. Edited by Arnold Kettle. London: Lawrence and Wishart.

Kirby, D. (2004). “Chekhov's influence on Shakespeare”, Virginia Quarterly Review, pp. 176-193.

Kote1iansky, S. S. (1927). Anton Chekhov: Literary and theatrical reminiscences. London: George Rutledge.

Kott, J. (1974). Shakespeare our contemporary. London: Norton Library.

Lefevre, A. (1987). "Beyond interpretations or the business of (re) writing". Comparative Literature Studies, 24 (1), p.17-39.

Lukács, G. (1962). The historical novel. London: Merlin Press.

Markowitz, Ch. (1968). The Markowitz Hamlet. London: Allen Lane, The Penguin Press.

Morris, W. (1950). The letters of William Morris to his family and friends. Edited by Philip Henderson. London: Longmans, Green \&Co.

Muchnic, H. (1963). Gorky to Pasternak: Six modern Russian Writers. London: Methuen.

Rayfield, D. (1985). "Chekhov and the literary tradition" in A Chekhov Companion. Edited by Toby Clyman. Westport, Connecticut: Greenwood. 
Rowe, E. (1976). Hamlet: A window on Russia. New York: New York UP.

Schofield, M. (1980). The ghosts of Hamlet. Cambridge: Cambridge UP.

Shakespeare, W. (1981). "Introduction" to Hamlet, Edited by Bernard Lott. London: Longman.

---. (2009). "The source of Hamlet" in Hamlet. Beirut: York press.

Simmons, E. J. (1970). Chekhov: A Biography. Chicago: Chicago UP.

Steiner, G.(1986). Antigones. Oxford: Clarendon Press.

Turgenev, E. (2009). "Hamlet and Don Quixote”, Translated by Leon Burnett. Colchester: Essex U.

Valency, M. (1965). The breaking string: The plays of Anton Chekhov. London: Oxford UP.

Watts, H. H. (1968). "Myth and drama”. Perspectives on drama. Edited by James L. Calderwood \& Harold E. New York: Oxford UP.

Whitaker, V. K. (1965). The Mirror up to nature: The techniques of Shakespeare's tragedies. California: The Huntington Library.

Wilson, J. D. (1962) What happens in Hamlet. Cambridge: Cambridge UP.

Winner, Th. G. (1956). "Chekhov's Seagull and Shakespeare's Hamlet: A study of a dramatic device”. American Slavic and East European Review, xv, p. (103-111). Print.

Yarmolinsky, A. (1969). The Russian literary imagination. New York: Funk and Wagn. 